\title{
Plant Genetic Resources and Food Security
}

Stakeholder Perspectives on the International Treaty on Plant Genetic Resources for Food and Agriculture

\section{Edited by Christine Frison, Francisco López and José T. Esquinas-Alcázar}

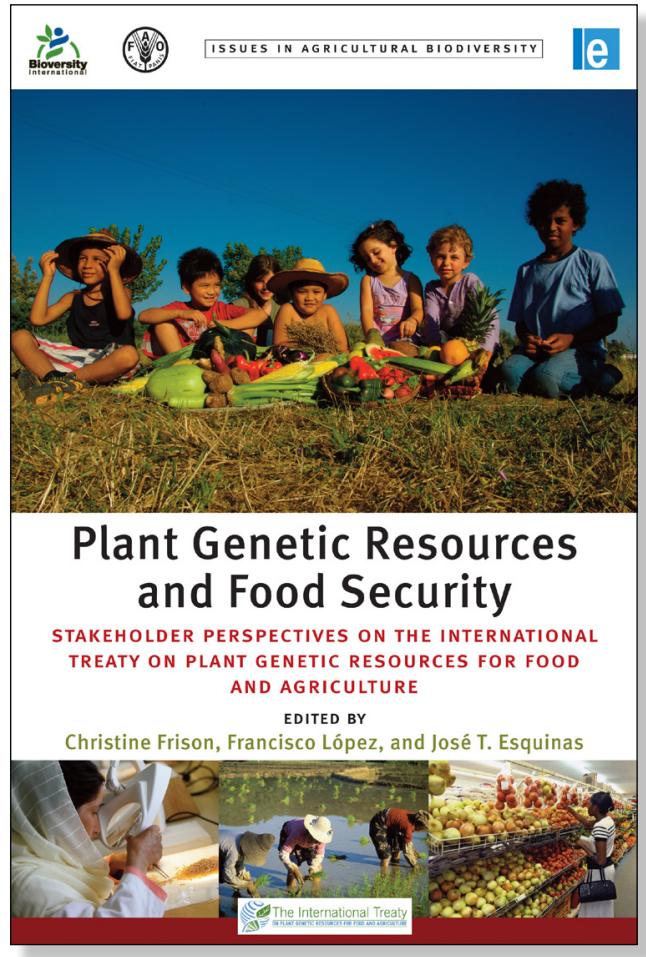

$P b \cdot £ 29.99 £ 23.99 \cdot 9781849712064$

$\mathrm{Hb} \cdot £ 85.0 \theta £ 68.00 \cdot 9781849712057$ 320 pages • July 2011

The International Treaty on Plant Genetic Resources for Food and Agriculture (ITPGRFA) is a pivotal piece of recent legislation, providing a route map for the use of such resources for sustainable agriculture and food security.

This book explains clearly the different interests and views at stake between all players in the global food chain. It touches upon many issues such as international food governance and policy, economic aspects of food and seed trade, conservation and sustainable use of food and agricultural biodiversity, hunger alleviation, ecological concerns, consumers' protection, fairness and equity between nations and generations, plant breeding techniques and socioeconomic benefits related to food local economies.

The book shows that despite the conflicting interests at stake, players managed to come to an agreement on food and agriculture for the sake of food security and hunger alleviation in the world.

Published with theFood and Agriculture Organisation (FAO) of the United Nations and with Bioversity International.

Christine Frison is a lawyer currently conducting a $\mathrm{PhD}$ research at the Catholic University of Louvain (Belgium) on international law and governance of plant genetic resources for food and agriculture.

Francisco López is Treaty Support Officer for the International Treaty on Plant Genetic Resources for Food and Agriculture.

José T. Esquinas-Alcázar is currently the Director of the Catedra on Studies on Hunger and Poverty of the University of Cordoba, and has worked for 30 years in FAO as Secretary of the FAO's intergovernmental Commission on Genetic Resources for Food and Agriculture.

\section{CONTENTS}

Dedication

Acknowledgements

List of Figures, Tables and Boxes

Notes on contributors

Preface Shakeel Bhatti and

Olivier De Schutter

Acronyms and

abbreviations

1. Introduction. A Treaty

to fight Hunger: Past

negotiations, present

situation, and future

challenges

Part I: Perspectives on the

Treaty by regions in the world

\section{Overview of Regional} Approaches

3. The African Regional

Group

4. The Asian Regional

Group

5. The European Regional Group

6. The Latin American and Caribbean Regional Group 7. The Near East Regional Group

8. The North American Regional Group

9. The South West Pacific Regional Group
Part II: Perspectives on the Treaty by stakeholders in the world food chain

10. International Non-Governmental Organizations 11. International Research Centres

12. The Seed Industry

13. Farmers' Communities

14. Genebank Curators

15. Plant Breeders

16. The Global Crop

Diversity Trust

17. Consumers

Part III: Experts' views on future challenges in implementing the Treaty: Trust and Benefit-sharing as the key

\section{Our Heritage is our}

Future

19. An innovative and transparent option for royalty payment under the ITPGRFA

20. Conclusions by the editors: Summary and analysis of issues raised by authors and further development of possible ways forward

Annex 1-4 Index 


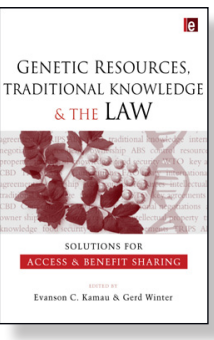

\section{Genetic Resources, Traditional Knowledge and the Law \\ Solutions for Access and \\ Benefit Sharing \\ Edited by Evanson C. Kamau and Gerd Winter}

$\mathrm{Hb} \cdot £ 80.00 £ 64.00$.

$9781844077939 \cdot 528$ pages August 2009

The Convention on Biological Diversity established a series of principles and requirements around access and benefit sharing (ABS) in order to increase transparency and equity in the international flow of genetic resources, yet few countries have been able to effectively implement them and ABS negotiations are often paralysed by differing interests. This book not only examines these complex challenges, but offers workable, policyoriented solutions. International contributors cover theoretical approaches, new significant national legislation, the concept of traditional knowledge, provider and user country measures and common solutions.

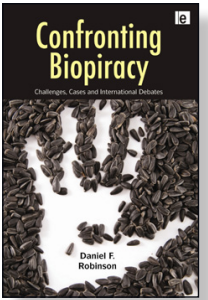

Confronting Biopiracy

Challenges, Cases and

International Debates

Daniel F. Robinson

$\mathrm{Pb} \cdot £ 24.99 £ 19.99$

$9781849714327 \cdot 208$ pages June 2011

"Biopiracy" refers either to the unauthorised extraction of biological resources, such as plants with medicinal properties, and associated traditional knowledge from indigenous peoples and local communities, or to the patenting of

spurious "inventions" based on such knowledge or resources without compensation. The aim of this book is to provide the most detailed, coherent analysis of the issue of biopiracy to date.

The book synthesises the rise of the issue and increasing use of the term by activists and negotiators in the World Trade Organization (WTO) and the Convention on Biological Diversity (CBD), to form a critical understa of the themes, implications and politics of biopiracy.
BIODIVERSITY LAW

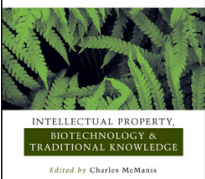

Biodiversity and the

Law

Intellectual Property

Biotechnology and

Traditional Knowledge Edited by Charles R.

\section{McManis}

$\mathrm{Pb} \cdot £ 45.00 £ 36.00$.

$9781844078165 \cdot 520$ pages $•$ October 2009

How do we promote global economic development, while simultaneously preserving local biological and cultural diversity? This authoritative volume, written by leading legal experts and biological and social scientists from around the world, aims to address this question in all of its complexity. The book focuses on biodiversity and examines what we are losing; addresses biotechnology and looks at whethe it is part of the solution or part of the problem examines traditional knowledge; looks at ethnobotany and bioprospecting and offers practical lessons from the vast and diverse experiences of the contributors.

\begin{tabular}{|c|c|c|c|c|c|}
\hline \multirow[b]{2}{*}{0} & TITLE & ISBN & $\begin{array}{l}\text { PRICE (£) } \\
\text { WITH DISCOUNT }\end{array}$ & QTY & TOTAL \\
\hline & Plant Genetic Resources and Food Security (Paperback) & 9781849712064 & $£ 23.99$ & & \\
\hline & Plant Genetic Resources and Food Security (Hardback) & 9781849712057 & $£ 68.00$ & & \\
\hline & Genetic Resources, Traditional Knowledge and the Law (Hardback) & 9781844077939 & $£ 64.00$ & & \\
\hline 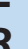 & Confronting Biopiracy (Paperback) & 9781849714327 & $£ 19.99$ & & \\
\hline & Biodiversity and the Law (Paperback) & 9781844078165 & $£ 36.00$ & & \\
\hline$=$ & Subtotal & & & & \\
\hline J & Postage \& Packaging UK: $£ 3.50$ & & & & \\
\hline & Europe Airmail: $£ 5+£ 2$ per additional book & & & & \\
\hline & RoW Airmail: $£ 7.50+£ 2$ per additional book & & & & \\
\hline & Total & & & & \\
\hline
\end{tabular}

Please post orders to:

Earthscan, FREEPOST RRUK-TTAX-XCRZ

Dunstan House, 14a St Cross Street, London EC1N 8XA

\section{PAYMENT OPTIONS}

1. I enclose a cheque/bankers draft payable to Earthscan (in sterling drawn on a UK bank) $\square$

\section{Please debit my Credit/Debit Card account number $\square$}
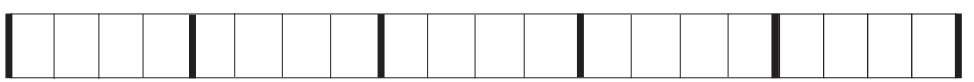

Telephone: +44 (0) 2078411930 • Fax: +44 (0) 2072421474

Email: orders@earthscan.co.uk.Website: www.earthscan.co.uk

Expiry date: Three Digit Security Number:

Issue No. or Valid From date (Switch only)

Signature:

Date:

3. Please send me a pro-forma invoice $\square$

(Note: this invoice will need to be paid before the books are dispatched)

4. We have an account set up with you - please bill us

Our Macmillan account number is:
Postcode

\section{YOUR DETAILS}

\author{
Name \\ Organisation
}

Address

Country

Tel. No.

E-mail 